\title{
HANNOVER RADIOCARBON MEASUREMENTS II
}

\author{
M. A. GEYH, H. SCHNEEKLOTH, and I. WENDT
}

Niedersächsisches Landesamt für Bodenforschung, Hannover

The results described herein are measurements performed in 1961. Sample preparation and conversion into acetylene have been described (Wendt, Schneekloth and Budde, 1962). In calculating errors we did not follow the procedure used in our Date List I, where only the standard deviations of counting rates were used. The errors attached to the dates listed below include systematic errors due to sample preparation and small changes in the counting characteristics of sample, background, and standard counting gas.

Some samples, especially gyttja and highly decomposed peat, did not contain sufficient cellulose residues. In these cases the humic-acid fractions were used, although they are not as reliable as dates based on the cellulose fraction. In the descriptions these sample are labeled "humic acid."

The authors wish to express their thanks to Ursula Wehmer and RoseMarie Westphal for assistance in chemical preparation and measurement of samples.

\section{SAMPLE DESCRIPTIONS}

I. GEOLOGIC SAMPLES

\section{A. Germany}

\section{Hv-36. Colmar, Niedersachsen}

$4260 \pm 190$

Peat from depth of 510 to $515 \mathrm{~cm}$ in core boring in the village Colmar $\left(53^{\circ} 19^{\prime} 30^{\prime \prime} \mathrm{N}\right.$ Lat, $8^{\circ} 21^{\prime} 13^{\prime \prime}$ E Long). Peat is overlain by marine silty clay. Coll. 1959 and subm. by Rudolpf Fleischmann and Heinz Voigt, Niedersächsisches Landesamt für Bodenforschung, Hannover (in the following text abbr. NLfB). Comment: sample dates the beginning of flooding of the Colmar area by the North Sea. From thickness of peat layers and earlier $\mathrm{C}^{14}$ dates (Wendt, Schneekloth and Budde, 1962), the date had been thought to be ca. 2000 B.c.

\section{Barnstorf bog series, Niedersachsen}

Peat from a surface digging in GrossesMoor, near Barnstorf $\left(52^{\circ} 42^{\prime} 06^{\prime \prime}\right.$ N Lat, $8^{\circ} 22^{\prime} 37^{\prime \prime}$ E Long). Profile description: 0 to $190 \mathrm{~cm}$, raised-bog peat; 190 to $225 \mathrm{~cm}$, Carex peat with birch and pine wood; 225 to $250 \mathrm{~cm}$, bogforest peat; 250 to $280 \mathrm{~cm}$, Carex peat with wood; 280 to $295 \mathrm{~cm}$, sandy bog-forest peat. Coll. 1959 by H. U. Steckhan; subm. by Heinrich Schneekloth.

\section{Hv-77. Barnstorf, 117 to $120 \mathrm{~cm}$}

$1820 \pm 75$

Much decomposed Sphagnum peat, directly below the recurrence horizon (= contact plane between underlying dark, much decomposed and overlying light, slightly decomposed Sphagnum peat).

Hv-75. Barnstorf, 200 to $218 \mathrm{~cm}$

$2980 \pm 100$

Carex peat. 
Hv-76. Barnstorf, 244 to $248 \mathrm{~cm}$

$2960 \pm 80$

Bog forest peat. Comment: Hv-75 dates the Carpinus immigration and the last Corylus maximum in the region. Hv-76 dates the beginning of bog growth and immigration of Fagus. Hv-77 dates the recurrence horizon of GrossesMoor, and the beginning of grain cultivation. There are no discrepancies between our dates and the pollen investigations of Schneider and Steckhan (1962).

\section{Hv-112. Lathen, Niedersachsen}

$\mathbf{2 2 0 0} \pm \mathbf{8 0}$

Humic acid fraction from humic soil with $3.8 \%$ organic matter from 65 to $70 \mathrm{~cm}$ depth $\left(52^{\circ} 50^{\prime} 30^{\prime \prime} \mathrm{N}\right.$ Lat, $7^{\circ} 12^{\prime} 8^{\prime \prime} \mathrm{E}$ Long). The profile shows a fossil podsolic soil at 64 to $70 \mathrm{~cm}$ depth below a recent podsolic soil at the surface. Coll. 1958 and subm. by Rudolf Lüders, NLfB. Comment: pollen content shows the sample probably belongs to the end of the Atlantic Period (Zone VII of Firbas, 4000-2500 B.C.). The results are discussed by Lüders (1961).

\section{Hv-129. Isernhagen, Niedersachsen \\ $1900 \pm 70$}

Roots from 75 to $130 \mathrm{~cm}$ depth in a digging in the village Isernhagen near Hannover (52 28 $30^{\prime \prime}$ Lat, 9 $9^{\circ} 45^{\prime} 52^{\prime \prime}$ E Long). Coll. 1960 and subm. by H. D. Lang, NLfB. Comment: a silty clayey layer above the roots was deformed, probably by freezing during early Dryas time. The roots were supposed to have belonged to vegetation that grew in the Alleröd layer. Date, much to young for Alleröd, is maximum for eolian sand, which overlies the deformed section.

\section{Weisses Moor series, Niedersachsen}

Peat from borings and peat diggings from the raised bog Weisses Moor near the village Kirchwalsede. Coll. 1960 and subm. by Heinrich Schneekloth. Samples date a recurrence horizon and characteristic features of pollen diagram.

Hv-135. Weisses Moor 13, 85 to $90 \mathrm{~cm}$

$990 \pm 90$

$\left(53^{\circ} 3^{\prime} 20^{\prime \prime} \mathrm{N}\right.$ Lat, $9^{\circ} 23^{\prime} 35^{\prime \prime} \mathrm{E}$ Long). Humic acid from slightly decomposed Sphagnum peat, $200 \mathrm{~cm}$ thick, overlying Scheuchzeria-cuspidata peat and Carex-bog-forest peat.

Hv-137. Weisses Moor 13, 215 to $225 \mathrm{~cm}$

$1560 \pm 90$

Humic acid from Scheuchzeria-cuspidata peat from the same boring as Hv-135. Comment: Hv-137 dates beginning of growth of light peat (lower part of Zone XI of Overbeck; see Schneekloth, 1962). Hv-135 dates beginning of intensive human settlement. According to Schneekloth (1962) settlement became important in the early Middle Ages.

Hv-139. Weisses Moor 37, 70 to $80 \mathrm{~cm}$ $2190 \pm \mathbf{1 5 0}$

$\left(53^{\circ} 3^{\prime} 35^{\prime \prime} \mathrm{N}\right.$ Lat, $9^{\circ} 21^{\prime} 50^{\prime \prime}$ E Long). Peat from 70 to $80 \mathrm{~cm}$ depth. In the profile $80 \mathrm{~cm}$ of slightly decomposed Sphagnum peat covers $70 \mathrm{~cm}$ of strongly decomposed Sphagnum peat.

Hv-139 a. Weisses Moor 37, humic acid

$1800 \pm 110$

Humic-acid fraction from $\mathrm{Hv}-139$. 
Hv-140. Weisses Moor 6, 100 to $110 \mathrm{~cm}$

$1870 \pm 100$

$\left(53^{\circ} 3^{\prime} 25^{\prime \prime}\right.$ N Lat, $9^{\circ} 24^{\prime} 38^{\prime \prime}$ E Long). Humic acid from peat from 100 to $110 \mathrm{~cm}$ depth. In the profile $110 \mathrm{~cm}$ of slightly decomposed Sphagnum peat covers $70 \mathrm{~cm}$ of strongly decomposed Sphagnum peat. Comment: humic-acid dates seem to establish that the recurrence horizon is of uniform age throughout the bog. The pollen study (Schneekloth, 1962) suggests that Hv-139 could be somewhat older than $\mathrm{Hv}$-140. The different values for Hv-139 show that the discrepancy may result from contamination by younger humic acid.

\section{Hv-128. Liebenau, Niedersachsen}

$1875 \pm 115$

Wood of a man-made bank protection from $200 \mathrm{~cm}$ depth in a surface digging near the town Liebenau $\left(52^{\circ} 36^{\prime} 57^{\prime \prime} \mathrm{N}\right.$ Lat, $9^{\circ} 8^{\prime} 26^{\prime \prime} \mathrm{E}$ Long), collected in river gravel beneath floodplain alluvium. Coll. 1960 and subm. by Konrad Richter, NLfB. Comment: date points to beginning of sedimentation of floodplain alluvium and sheds light on the history of human settlement. See also sample Hv-15, $1550 \pm 80$, in Wendt, Schneekloth and Budde, 1962.

\section{Hv-134. Badbergen, Niedersachsen}

$12,600 \pm 240$

Silty sand with remnants of vegetation from $420 \mathrm{~cm}$ depth from Sandmann sand pit near Badbergen (52 $38^{\prime} 00^{\prime \prime} \mathrm{N}$ Lat, $7^{\circ} 58^{\prime} 28^{\prime \prime} \mathrm{E}$ Long). Coll. 1960 and subm. by Konrad Richter. Comment: pollen study by H. Schneekloth shows horizon at $310 \mathrm{~cm}$ belongs to the Younger Dryas (ca. 8500 B.c.).

\section{Hv-98-99-90. Kiel, Schleswig-Holstein}

$11,270 \pm 130$

Birch and willow wood from 22.35 to $26.30 \mathrm{~m}$ depth in core boring in Kiel Harbor, near Kiel Castle (54 $19^{\prime} 40^{\prime \prime}$ N Lat, $10^{\circ} 8^{\prime} 51^{\prime \prime}$ E Long). Wood from three samples was combined before pretreatment. The profile shows marine sediments down to $20 \mathrm{~m}$ depth, above interbedded gravel, sand, and gyttja. Coll. 1959 and subm. by Alfred Dücker, Geol. Landesamt Schleswig-Holstein. Comment: samples date one or more interstadials of the last (Weichsel) glaciation.

\section{Viel-Moor series, Schleswig-Holstein}

Peat from surface diggings in the raised bog Viel-Moor, near Barnstedt ( $53^{\circ} 47^{\prime} 00^{\prime \prime} \mathrm{N}$ Lat, $9^{\circ} 51^{\prime} 36^{\prime \prime} \mathrm{E}$ Long). The profile shows two sequences of strongly decomposed below slightly decomposed Sphagnum-peat, i.e. there are two recurrence horizons. Coll. 1960 by F. R. Averdieck; subm. by Alfred Dücker.

Hv-93. Viel-Moor, 84 to $90 \mathrm{~cm}$

$1410 \pm 110$

Peat from $6 \mathrm{~cm}$ above the upper recurrence horizon.

Hv-94. Viel-Moor, 91 to $98 \mathrm{~cm}$

$1550 \pm 110$

Peat from $7 \mathrm{~cm}$ below the upper recurrence horizon. Comment: samples are correlated by pollen with the upper part of Zone IX of Firbas. The stratigraphy of Viel-Moor is given by Averdieck (1957).

Hv-95. Viel-Moor, 111 to $117 \mathrm{~cm}$

$1775 \pm 115$

Peat from $6 \mathrm{~cm}$ above the lower recurrence horizon. 
Hv-96. Viel-Moor, 123 to $129 \mathrm{~cm}$

$1800 \pm 115$

Peat from $6 \mathrm{~cm}$ below the lower recurrence horizon. Comment: samples are correlated by pollen with the middle part of Zone IX of Firbas. Dates do not conflict with the concept of Overbeck et al. (1957) as to the ages of recurrence horizons in North Germany or with the special investigations of the age of the recurrence horizon of Wittmoor near Hamburg by Averdieck and Münnich (1957).

\section{Miele series, Schleswig-Holstein}

Peat and gyttja from borings in the Miele River area. Coll. 1959 by F. R. Averdieck; subm. by Alfred Dücker. Samples date various phases of flooding of the Miele area by the North Sea.

Hv-71. Fiel

$2370 \pm 90$

(54. ${ }^{\prime} 8^{\prime} 25^{\prime \prime} \mathrm{N}$ Lat, $9^{\circ} 8^{\prime} 13^{\prime \prime}$ E Long). Gyttja from 86 to $95 \mathrm{~cm}$ below surface, underlain and overlain by marine clay beneath surface peat.

Hv-65. Bargenstedt, 40 to $47 \mathrm{~cm}$

$1850 \pm 120$

$\left(54^{\circ} 6^{\prime} 46^{\prime \prime} \mathrm{N}\right.$ Lat, $9^{\circ} 7^{\prime} 22^{\prime \prime}$ E Long). Humic acid from Phragmites peat from 40 to $47 \mathrm{~cm}$ depth, underlain and overlain by marine clay.

Hv-66. Bargenstedt, 56 to $62 \mathrm{~cm}$

$2280 \pm 100$ Hv-65.

Clayey gyttja from 56 to $62 \mathrm{~cm}$ below surface in the same boring as

Hv-67. Volkerswurth-Sïd, 47 to $54 \mathrm{~cm}$

$2250 \pm 120$

( $54^{\circ} 8^{\prime} 30^{\prime \prime} \mathrm{N}$ Lat, $9^{\circ} 6^{\prime} 29^{\prime \prime}$ Long). Gyttja from 47 to $54 \mathrm{~cm}$ below surface, underlain and overlain by marine clay.

Hv-67 a. Volkerswurth-Süd, 47 to 54, humic acid $1680 \pm 90$

Humic-acid fraction of Hv-67.

Hv-68. Volkerswurth-Süd, 40 to $45 \mathrm{~cm}$

$1820 \pm 100$

Humic acid from Phragmites peat from 40 to $45 \mathrm{~cm}$ depth in the same boring as Hv-67.

Hv-69. Volkerswurth-Süd, 58 to $63 \mathrm{~cm}$

$1870 \pm 130$

Humic acid from gyttja from 58 to $63 \mathrm{~cm}$ depth in the same boring as Hv-67. Comment: samples of the Miele series date a penultimate marine submergence ( $u_{2}$ of Dechend, 1956). Hv-66 and Hv-67 agree with expectation. Humic acid samples seem to be too young.

\section{Hv-159. Langenau, Baden-Württemberg}

$2300 \pm 105$

Wood from a gravel pit, $4 \mathrm{~m}$ depth $\left(48^{\circ} 26^{\prime} 14^{\prime \prime} \mathrm{N}\right.$ Lat, $10^{\circ} 6^{\prime} 11^{\prime \prime} \mathrm{E}$ Long). The profile shows a stump horizon at $4 \mathrm{~cm}$ below surface, overlain by gravel with humic inclusions and underlain by gravel. Coll. 1960 and subm. by Paul Groschopf, Geol. Landesamt Baden-Württemberg. Comment: at $450 \mathrm{~cm}$ beneath the floodplain of the Iller River, in the Ulm district, an extensive horizon with stumps and peat occurs. Pollen study suggested a late Neolithic or 
Bronze Age correlation. The result has been confirmed by other investigations (Graul and Groschopf, 1952).

Hv-160. Plïderhausen, Baden-Württemberg $\quad 3140 \pm 100$

Wood from a gravel pit, $260 \mathrm{~cm}$ depth $\left(48^{\circ} 47^{\prime} 16^{\prime \prime} \mathrm{N}\right.$ Lat, $9^{\circ} 36^{\prime} 29^{\prime \prime}$ E Long). Coll. 1960 and subm. by Eugen Eisenhut, Geol. Landesamt BadenWürttemberg. Comment: dates floodplain sediments of Rems River. Although younger than expected, the date compares with $\mathrm{Hv}$-161, below.

Hv-162. Weissach, Baden-Württemberg $1630 \pm 105$

Wood from H. Gauger excavation $\left(48^{\circ} 48^{\prime} 16^{\prime \prime} \mathrm{N}\right.$ Lat, $8^{\circ} 51^{\prime} 2^{\prime \prime} \mathrm{E}$ Long), $230 \mathrm{~cm}$ depth beneath clayey silt. Coll. 1960 and subm. by Eugen Eisenhut. Comment: dates the basement of a valley.

Hv-165. Friedrichshafen, Baden-Württemberg $\quad 2980 \pm 100$

Wood below diocesan building foundation, Friedrichshafen $\left(47^{\circ} 39^{\prime} 23^{\prime \prime}\right.$ $\mathrm{N}$ Lat, $9^{\circ} 29^{\prime} 5 \mathrm{l}^{\prime \prime} \mathrm{E}$ Long), $4 \mathrm{~m}$ depth, from sand and gravel below water table. Coll. 1961 and subm. by Paul Groschopf. Comment: dates sand and gravel sedimentation related to postglacial lake-level fluctuation of the Bodensee.

\section{Hv-161. Regensburg (city), Bayern $\quad 3270 \pm 100$}

Wood from oak stump at $5 \mathrm{~m}$ depth, beneath sand and gravel of Donau River floodplain $\left(49^{\circ} 0^{\prime} \mathrm{N}\right.$ Lat, $12^{\circ} 7^{\prime}$ E Long). Coll. 1959 and subm. by Paul Groschopf. Comment: as stratigraphic position is similar to $\mathrm{Hv}-159$, an age of ca. 2000 yr was predicted. Evidently postglacial river sedimentation has not been uniform.

\section{B. Poland}

\section{Hv-122. Kruklin Lake, Gizycko}

$11,390 \pm 210$

Wood from a fossiliferous soil horizon, 35 to $40 \mathrm{~cm}$ depth $\left(45^{\circ} 3^{\prime} 30^{\prime \prime} \mathrm{N}\right.$ Lat, $21^{\circ} 54^{\prime} 0^{\prime \prime} \mathrm{E}$ Long). The sandy and gravelly sample layer, which for 100 yr has lain above the water level of the lake, is covered successively by $30 \mathrm{~cm}$ of lake clay and $32 \mathrm{~cm}$ of lacustrine chalk with shells. Coll. 1960 by Stasiak Jadwiga; subm. by Edmund Rutkowsky, Inst. Geol., Warszawa. Comment: pollen study of the sample horizon by Boriosko Duzakowa indicated Pleistocene or early Holocene Age, in agreement with the date.

\section{Hv-123. Laska near Brusy}

$9680 \pm 190$

Gyttja, noncalcareous, from a core boring ( $53^{\circ} 57^{\prime} 22^{\prime \prime} \mathrm{N}$ Lat, $17^{\circ} 32^{\prime} 18^{\prime \prime}$ E Long). Coll. 1960 by Wadislaw Sonina; subm. by Edmund Rutkowsky. Comment: pollen study by Boriosko Duzakowa predicted an age of not more than $10,000 \mathrm{yr}$.

\section{Hamernia series, Poland}

Peat from a core boring from Hamernia near Jaroslaw $\left(55^{\circ} 5^{\prime} \mathrm{N}\right.$ Lat, $22^{\circ} 58^{\prime}$ E Long), overlain by sand and gravel and underlain by gyttja and clay. Coll. 1960 by Kazimiera Mamakowa; subm. by Edmund Rutkowsky. 
Sandy peat from 180 to $187 \mathrm{~cm}$ depth.

Hv-172. Hamernia II

Silty peat from 222 to $230 \mathrm{~cm}$ depth. Comment: the peat of Hamernia was classified by Szafer (1931) as being older Pleistocene, and by Rühle (1952) as being postglacial.

\section{ARCHAEOLOGIC SAMPLES}

\section{Emsland Plaggenboden series, Niedersachsen}

Humic sand from Plaggenboden layers (man-made layers) built by piling up, over centuries, the upper humic layer of the mineral soil dug from below a heath (Callunetum), to act as fertilizer. Coll. 1960 and subm. by Hans Fastabend, NLfB.

\section{Hv-141. Plaggenboden I}

$2475 \pm 115$

Humic sand filling a ditch beneath a Plaggenboden near Engden $\left(52^{\circ} 23^{\prime}\right.$ $41^{\prime \prime} \mathrm{N}$ Lat, $7^{\circ} 9^{\prime} 19^{\prime \prime} \mathrm{E}$ Long), 55 to $60 \mathrm{~cm}$ depth.

\section{Hv-143. Plaggenboden II}

$1300 \pm 110$

Humic sand from base of a Plaggenboden near Drievorden $\left(52^{\circ} 22^{\prime} 37^{\prime \prime}\right.$ N Lat, $7^{\circ} 12^{\prime} 32^{\prime \prime}$ E Long), 70 to $80 \mathrm{~cm}$ depth.

\section{Hv-145. Plaggenboden III}

$1250 \pm 115$

Humic sand from base of a Plaggenboden near Leschede $\left(52^{\circ} 24^{\prime} 18^{\prime \prime} \mathrm{N}\right.$ Lat, $7^{\circ} 10^{\prime} 27^{\prime \prime}$ E Long), 70 to $75 \mathrm{~cm}$ depth. Comment: Raupach (1955) and Fastabend and Raupach (1961) believed the use of Plaggen to have begun later than A.D. 700. This is confirmed by our dates Hv-143 and Hv-145. Hv-141, from below the Plaggenboden, was expected to be considerably older. See also Niemeier (1959).

\section{Hv-146. Göttingen, chair}

Wood from an ancient chair in the Museum of Göttingen, Niedersachsen. Subm. 1960 by E. F. Hellige, Mus. of Göttingen. Comment: dates a chair believed to be either a 13th Century object from the monastery of Pöhlde, or a 19th Century imitation.

\section{REFERENCES}

Averdieck, F. R., 1957, Zur Geschichte der Moore und Wälder Holsteins: Nova acta Leopoldina, Neue Folge, no. 130, v. 19, p. 1-52.

Averdieck, F. R., and Münnich, K. O., 1957, Palynologische Betrachtungen zur Siedlungsgeschichte im Norden Hamburgs unter Zuhilfenahme neürer Datierungsmethoden: Hammaburg, v. 5 , no. 11 , p. $9-22,4$ pls.

Dechend, W., 1956, Der Ablauf der holozänen Nordsee-Transgression im oldenburgischostfriesischen Raum insbesondere im Gebiet von Jever i.O.: Geol. Jahrb., v. 72, p. 295

Fastabend, H., and von Raupach, F., 1961, Zur Kenntnis der Plaggenböden in Nordwestdeutschland: Geol. Jahrb., v. 78, p. 139.

Graul, Hans and Groschopf, Paul, 1952, Geologische und morphologische Betrachtungen zum Illerschwemmkegel bei Ulm: Naturforschende Gesellschaft, Bericht, v. 5, p. 3-27 [Augsburg].

Groschopf, P., 1961, Beiträge zur Holozänstratigraphie Südwestdeutschlands nach $\mathrm{C}^{14}$. Bestimmungen: Geol. Jahrb. Landesamt Baden-W., v. 4, p. 137. 
Lüders, R., 1961, Altersbestimmung an einem doppelten Podsolprofil aus dem Emsland: Zeitschrift für Pflanzenernährung, Düngung und Bodenkunde, v. 94, p. 47.

Niemeier, G., 1959, Datierungen der Kulturlandwirtschaftsgeschichte Norwestdeutschlands: Braunschweigische Wissenschafliche Gesellschaft, Abhandlungen, v. 11, p. 87.

Overbeck, F., Münnich, K. O., Aletsee, L. and Averdieck, F. R., 1957, Das Alter des "Grenzhorizonts" norddeutscher Hochmoore nach Radiocarbondatierungen: Flora, v. 145 , p. 37-71.

Raupach, von F., 1955, Die Plaggenböden des südwestlichen Ammerlandes: Oldenb. Jahrb., v. 55 , no. 2, p. 125 .

Rühle, E., 1952, Geological section of Lubaczowka valley near Hamernia: Warsaw Panstwowy Inst. Geol. Bull., v. 66.

Schneekloth, H., 1962, Beiträge zur Kenntnis niedersächsischer Torflagerstätten, II. Das Weisse Moor bei Kirchwalsede (Krs. Rotenburg Hannover): Geol. Jahrb. Beiheft no. 55 .

Schneider, S., and Steckhan, H. U., 1962, Beiträge zur Kenntnis niedersächsischer Torflagerstätten. III. Das Grosse Moor bei Barnstorf [Krs. Grafschaft Diepholz]: Geol Jahrb., Beicheft no. 55 .

Szafer, W., 1931, The oldest Interglacial in Poland: Internat. Academie Polonaise des Sciences et des Lettres, Bull., ser. B. [Cracovic].

Wentd, I., Schneekloth, H., and Budde, E., 1962, Hannover radiocarbon measurements I: Radiocarbon, v. 4, p. 100-108. 